\title{
In Vitro Inhibition of Chick Embryo Lysyl Hydroxylase by Homogentisic Acid
}

\section{A PROPOSED CONNECTIVE TISSUE DEFECT IN ALKAPTONURIA}

\author{
John C. Murray, Kenneth A. Lindberg, and Sheldon R. Pinnell \\ From the Department of Medicine, Duke University Medical Center, Durham, \\ North Carolina 27710
}

\begin{abstract}
A B S T R A C T Homogentisic acid inhibits the in vitro activity of chick embryo lysyl hydroxylase, a microsomal enzyme which catalyzes the transformation of certain lysyl residues in collagen to hydroxylysine. Chick embryo lysyl hydroxylase activity was measured as specific tritium release as tritium water from a $[4,5-$ ${ }^{3} \mathrm{H}$ ]lysine-labeled unhydroxylated collagen substrate prepared from chick calvaria. Kinetic studies revealed a linear, noncompetitive type of inhibition with respect to collagen substrate with a $K i$ of 120-180 $\mu \mathrm{M}$. The inhibition by homogentisic acid was reversible in that enzyme activity could be restored after dialysis of preincubated mixtures of homogentisic acid with enzyme or substrate. The inhibition by homogentisic acid was competitive with respect to ascorbic acid, and the addition of reducing agents, such as ascorbic acid or 1,4-dithiothreitol, protected lysyl hydroxylase activity from homogentisic acid inhibition.
\end{abstract}

In organ cultures of embryonic chick calvaria, biosynthesis of hydroxylysine-derived intermolecular collagen cross-links was inhibited in a dose-dependent manner by 0.5-5 $\mathrm{mM}$ homogentisic acid. Because homogentisic acid inhibits the formation of hydroxylysine in a cell-free assay and in organ cultures, this compound must pass into the cells of calvaria to inhibit intracellular hydroxylysine formation and subsequently to diminish the reducible intermolecular cross-links of the newly synthesized collagen. We

This is publication no. 17 of the Dermatological Research Laboratories of Duke University. An abstract of this work appeared in 1976. Clin. Res. 24: 15A.

Dr. S. R. Pinnell is an investigator of the Howard Hughes Medical Institute. Dr. K. A. Lindberg is a fellow of the Dermatology Foundation. Mr. J. C. Murray was a Syntex Summer Research Fellow and a Summer Fellow of the Howard Hughes Medical Institute.

Received for publication 29 September 1976 and in revised form 25 February 1977. propose that the inhibition of lysyl hydroxylase and the resulting hydroxylsine-deficient, structurally modified collagen may be clinically significant in the defective connective tissue found in alkaptonuric patients.

\section{INTRODUCTION}

Hydroxylysine, an essentially unique amino acid found in collagen, is critically important for the structural function of collagen. As the major constituent of most connective tissues, collagen supports the structural integrity of the body by the remarkable tensile strength of the collagen fibers. This stability results from the unique configuration and attachment of collagen molecules to each other. Covalent cross-links are formed between hydroxylysine side chains and hydroxyallysine or allysine to lock collagen molecules into place (1-3). These intermolecular covalent linkages prevent slippage of adjacent molecules to maintain high tensile strength. In addition, hydroxylysine is an attachment site for carbohydrate to collagen, as galactose and glucosylgalactose are O-glycosidically linked to hydroxyl groups of various hydroxylysine residues $(4,5)$. Although the effect of glycosylation of hydroxylysine on cross-link formation is not entirely understood, the isolation of collagen cross-links with carbohydrate derivatives implies some functional or regulatory relationship $(6,7)$.

Because hydroxylysine participates directly in intermolecular cross-linking, a decrease in hydroxylysine formation would be expected to alter cross-link formation. Hydroxylysine is formed intracellularly as a posttranslational modification of certain lysine residues in collagen by the action of lysyl hydroxylase (E.C. 1.14.11.4). The in vitro activity of lysyl hydroxylase from chick embryos is inhibited by homogentisic acid, when measured as specific tritium release as 
tritiated water from an $\mathbf{L}-\left[4,5-{ }^{3} \mathrm{H}\right]$ lysine-labeled unhydroxylated collagen substrate (8). Inasmuch as homogentisic acid inhibits hydroxylysine formation in a cell-free assay, we were interested in whether or not homogentistic acid could enter into the cell effectively, inhibit hydroxylsine formation intracellularly, and subsequently diminish intermolecular collagen cross-linking in a tissue culture system. Our present investigations were designed to characterize the inhibition of hydroxylysine formation by homogentisic acid and to determine the effectiveness of homogentisic acid as a specific inhibitor of collagen cross-link formation. We propose that the inhibition of lysyl hydroxylase by homogentisic acid may explain the degenerative connective tissue found in patients with alkaptonuria.

\section{METHODS}

Purification of lysyl hydroxylase. The preparation of lysyl hydroxylase was modified from the procedure of Kivirikko and Prockop (9). $100 \mathrm{~g}$ of decapitated and eviscerated 16day-old chick embryos were mixed with $100 \mathrm{ml}$ of $0.2 \mathrm{M}$ $\mathrm{NaCl}, 0.1 \mathrm{M}$ glycine, $50 \mu \mathrm{M}$ 1,4-dithiothreitol (Cyclo Chemical, Los Angeles, Calif.), $20 \mathrm{mM}$ Tris- $\mathrm{HCl}$ buffer adjusted to $\mathrm{pH} 7.5$ at $4^{\circ} \mathrm{C}$. The mixture was homogenized in a blender (John Oster Manufacturer Co., Milwaukee, Wisc.) at full speed for $30 \mathrm{~s}$ and then by Polytron (Brinkmann Instruments, Inc., Westbury, N. Y.) at full speed for $1 \mathrm{~min}$. This homogenate was made $0.1 \%$ in Triton X-100 and stirred for $2 \mathrm{~h}$ at $4^{\circ} \mathrm{C}$ and then heated to $37^{\circ} \mathrm{C}$ for $15 \mathrm{~min}$. The homogenate was centrifuged $500 \mathrm{~g}$ for $10 \mathrm{~min}$ and then the supernate was centrifuged $100,000 \mathrm{~g}$ for $1 \mathrm{~h}$. The supernate was removed and solid $\left(\mathrm{NH}_{4}\right)_{2} \mathrm{SO}_{4}$ (Allied Chemical Corp., Morristown, N. J.) was slowly stirred into solution until a final concentration of $0.72 \mathrm{M}$. The solution was stirred $1 \mathrm{~h}$ and was centrifuged $15,000 \mathrm{~g}$ for $20 \mathrm{~min}$. The supernate was removed and solid $\left(\mathrm{NH}_{4}\right)_{2} \mathrm{SO}_{4}$ was slowly stirred into solution until a final concentration of $1.31 \mathrm{M}$. The solution was stirred $1 \mathrm{~h}$ and was centrifuged $15,000 \mathrm{~g}$ for $20 \mathrm{~min}$. The pellet was dissolved in $0.15 \mathrm{M} \mathrm{NaCl}, 0.1 \mathrm{M}$ glycine, $50 \mu \mathrm{M}$ 1,4-dithiothreitol, and $20 \mathrm{mM}$ Tris- $\mathrm{HCl}$ buffer adjusted to $\mathrm{pH} 7.4$ at $4^{\circ} \mathrm{C}$. The enzyme preparation in a volume of $50 \mathrm{ml}$ was dialyzed against 4 liters of the same buffer with three changes during $18 \mathrm{~h}$. The sample was diluted to a protein concentration of $30 \mathrm{mg} / \mathrm{ml}$ and was centrifuged at $15,000 \mathrm{~g}$ for 30 min. The supernate was stored at $-70^{\circ} \mathrm{C}$. Protein concentration was determined by the spectrophotometric method of Layne (10).

Assay for lysyl hydroxylase activity. Lysine-labeled unhydroxylated collagen substrate was prepared by incubating calvaria from two dozen 16-day-old chick embryos at $37^{\circ} \mathrm{C}$ with $1 \mathrm{mM} \alpha, \alpha^{\prime}$-dipyridyl, $150 \mu \mathrm{g}$ ascorbic acid, $300 \mathrm{U}$ penicillin, $300 \mu \mathrm{g}$ streptomycin in $3.0 \mathrm{ml}$ of Dulbecco's lysine-free minimal essential media (Grand Island Biological Co., Grand Island, N. Y.). $400 \mu \mathrm{Ci}$ of $\mathrm{L}-\left[4,5-{ }^{3} \mathrm{H}\right]$ lysine (New England Nuclear, Boston, Mass.; specific activity 1 $\mathrm{mCi} / \mathrm{ml}$ ) was added and the culture was incubated at $37^{\circ} \mathrm{C}$ for $24 \mathrm{~h}$ in a reciprocal water bath shaker. The calvaria were homogenized with $8 \mathrm{ml}$ distilled water using a Polytron (Brinkmann Instruments) at full speed for $1 \mathrm{~min}$ and the homogenate was centrifuged at $15,000 \mathrm{~g}$ for $1 \mathrm{~h}$. The supernate was dialyzed against 2 liters of $20 \mathrm{mM}$ Tris$\mathrm{HCl}$ buffer ajusted to $\mathrm{pH} 7.6$ at $4^{\circ} \mathrm{C}$ with three changes during $18 \mathrm{~h}$. The substrate preparation was placed in boiling water for $10 \mathrm{~min}$ to remove endogenous enzyme activity. The sample was centrifuged at $15,000 \mathrm{~g}$ for $30 \mathrm{~min}$ and the supernate was stored at $-70^{\circ} \mathrm{C}$ in $2-\mathrm{ml}$ aliquots. Because different unhydroxylated collagen substrate preparations incorporated varying amounts of labeled lysine residues, each experiment was run with the same substrate preparation.

Lysyl hydroxylase activity was measured by a tritiumrelease assay (11). The incubation mixture contained in a volume of $1.5 \mathrm{ml},\left(6.0 \times 10^{5} \mathrm{dpm}\right) L-\left[4,5{ }^{3} \mathrm{H}\right] l y s i n e$ collagen substrate, $0.5-1.5 \mathrm{mg}$ partially purified lysyl hydroxylase, $50 \mathrm{mM}$ Tris- $\mathrm{HCl} \mathrm{pH} 7.8,0.5 \mathrm{mM} \alpha$-ketoglutarate, $0.05 \mathrm{mM}$ $\mathrm{FeSO}_{4}, 0.5 \mathrm{mM}$ ascorbic acid, $0.1 \mathrm{mM}$ 1,4-dithiothreitol, $2.25 \mathrm{mg}$ bovine serum albumin, $0.15 \mathrm{mg}$ catalase (Calbiochem, San Diego, Calif.). The reaction was initiated by addition of substrate, and samples were incubated at $37^{\circ} \mathrm{C}$ for $90 \mathrm{~min}$. The reaction was terminated by addition of $0.1 \mathrm{ml}$ of $50 \%$ TCA. Tritiated water was collected by vacuum distillation. $1.0 \mathrm{ml}$ of the distilled sample was mixed with $10 \mathrm{ml}$ of Aquasol (New England Nuclear) for counting in a Packard Tri-Carb liquid scintillation counter (Packard Instrument Co., Inc., Downers Grove, Ill.). The counting efficiency was $23 \%$.

Collagenase digestion. The newly synthesized collagen content of the substrate was determined from a modified method of Diegelmann et al. (12). The same procedure was used with $50 \mathrm{U}$ of form III collagenase (Advance Biofacturers Corp., Lynbrook, N. Y.) per assay. The percent collagen present in a portion of analyzed substrate was determined on the basis that chick embryo skin type I collagen contains $3.4 \%$ lysine and hydroxylysine residues (13), whereas noncollagen proteins contain $6.5 \%$ lysine and no hydroxylysine (14). The formula of Diegelmann and Peterkofsky (15) was modified to account for the fact that collagen contains $52 \%$ fewer lysine residues than other proteins:

$\%$ collagen $=\mathrm{dpm}$ in collagenase digest/

$(\mathrm{dpm}$ in residue $\times 0.52)$

$+(\mathrm{dpm}$ in collagenase digest $) \times 100$.

Inhibition by homogentisic acid. Solutions of $15 \mathrm{mM}$ homogentisic acid (Sigma Chemical Co., St. Louis, Mo.) were prepared with distilled water and $0.1 \mathrm{ml}$ of the homogentisic acid solution was added to the in vitro assay system after addition of all other components. This procedure was followed to obtain the inhibition curves and the kinetic data. To test whether homogentisic acid binds reversibly or irreversibly to either partially purified lysyl hydroxylase or the unhydroxylated collagen substrate the following experiment was designed. Partially purified lysyl hydroxylase $\left(15 \mathrm{mg}\right.$ ) and $\mathrm{L}-\left[4,5-{ }^{3} \mathrm{H}\right]$ lysine unhydroxylated collagen substrate $\left(5.9 \times 10^{6} \mathrm{dpm}\right)$ were mixed separately with or without $15 \mathrm{mM}$ homogentisic acid, each in the presence or absence of cofactors. Cofactors included $0.05 \mathrm{mM}$ $\mathrm{FeSO}_{4}, 0.5 \mathrm{mM}$ ascorbic acid, $0.1 \mathrm{mM}$ 1,4-dithiothreitol, and $0.5 \mathrm{mM} \alpha$-ketoglutarate. The volume of each solution was $1.5 \mathrm{ml}$. The solutions were mixed by end-over-end tumbling with a Multi-Purpose Rotater (Scientific Industries, Inc., Bohemia, N. Y.) for $2 \mathrm{~h}$ at $4^{\circ} \mathrm{C}$. An aliquot $(0.1 \mathrm{ml})$ was taken from each of the eight solutions for assay. In the assays testing the four aliquots of lysyl hydroxylase, each incubation mixture contained in a volume of $1.5 \mathrm{ml}$, $\left(6.5 \times 10^{5} \mathrm{dpm}\right) \quad \mathrm{L}-\left[4,5^{-3} \mathrm{H}\right]$ collagen substrate, and other components listed above for the lysyl hydroxylase assay. In the assays of the four aliquots containing collagen substrate, each incubation mixture contained in a volume of $1.5 \mathrm{ml}, 1 \mathrm{mg}$ lysyl hydroxylase, $\left(3.9 \times 10^{5} \mathrm{dpm}\right) \mathrm{L}-\left[4,5-{ }^{3} \mathrm{H}\right]-$ 
collagen substrate, and other components listed above. The four containing lysyl hydroxylase were dialyzed against 4 liters of $0.05 \mathrm{M} \mathrm{NaCl}, 20 \mathrm{mM}$ Tris- $\mathrm{HCl}$ buffer adjusted to pH 7.4 at $4^{\circ} \mathrm{C}$ with five changes over $48 \mathrm{~h}$. The other four containing substrate were dialyzed against 4 liters of $20 \mathrm{mM}$ Tris- $\mathrm{HCl}$ buffer adjusted to $\mathrm{pH} 7.8$ at $4^{\circ} \mathrm{C}$ with five changes over $48 \mathrm{~h} .0 .1-\mathrm{ml}$ aliquots were taken for assay, and the incubation mixtures were prepared similarly to those before dialysis. Controls for these experiments were incubation mixtures without homogentisic acid before and after dialysis.

Kinetic analysis was performed with a modified assay system without catalase, bovine serum albumin, and 1,4dithiothreitol. The modified assay system contained $0.7 \mathrm{mg}$ lysyl hydroxylase and $6.6 \times 10^{6} \mathrm{dpm} / \mathrm{ml}$ unhydroxylated collagen substrate. The system without dithiothreitol, catalase, and albumin gave $83 \%$ of whole system activity. The assay was incubated at $37^{\circ} \mathrm{C}$ for $60 \mathrm{~min}$. All lines were plotted according to least squares method (16). Analysis of the unhydroxylated collagen substrate preparation by the collagenase-digestion method revealed that $69 \%$ of the protein was collagen. In an assay with $0.066 \mathrm{ml}$ collagen substrate, approximately $7.5 \times 10^{4} \mathrm{dpm}$ or $\left(6.6 \times 10^{6} \times 0.066 \times 0.69\right.$ $\times 1 / 4) \mathrm{dpm}$ of lysine residues were available for hydroxylation. Based on the premise that 7 of a total 34 lysine residues are hydroxylated (10), the assay with $0.066 \mathrm{ml}$ substrate released $3,700 \mathrm{dpm}$ which indicated the maximum extent $(5 \%)$ of hydroxylation.

The effect of excess ferrous ion and $\alpha$-ketoglutarate was investigated by varying the concentration of ferrous ion from 0.075 to $0.25 \mathrm{mM}$ or that of $\alpha$-ketoglutarate from 0.75 to $2.5 \mathrm{mM}$ in the complete assay before addition of $0.5 \mathrm{mM}$ homogentisic acid. The effect of ascorbic acid, 1,4dithiothreitol, D-isoascorbic acid (Sigma Chemical Co.), and dehydroascorbic acid ( $\mathrm{K} \& \mathrm{~K}$ Laboratories, Inc., Plainview, N. Y.) on homogentisic acid inhibition of lysyl hydroxylase was investigated by adding the reducing agent or ascorbic acid analogue to the modified assay system without catalase, bovine serum albumin, and 1,4-dithiothreitol. This modified assay system contained $0.02 \mathrm{mM}$ ascorbic acid and was incubated at $37^{\circ} \mathrm{C}$ for $60 \mathrm{~min}$.

Cross-link analysis. Analysis of intermolecular crosslinks was modified from the procedure of Bailey et al. (17). 18 calvaria from 16-day-old chick embryos were incubated in $3 \mathrm{ml}$ of Dulbecco's lysine-free minimal essential media (Grand Island Biological Co.) at $37^{\circ} \mathrm{C}$ with $150 \mu \mathrm{g}$ ascorbic acid, $300 \mathrm{U}$ penicillin, and $300 \mu \mathrm{g}$ streptomycin. Four culture systems were prepared: a control without additions, as well as $5 \mathrm{mM}, 1 \mathrm{mM}$, and $0.5 \mathrm{mM}$ homogentisic acid. $20 \mu \mathrm{Ci}$ of $\mathrm{L}^{-\left[{ }^{14} \mathrm{C}\right] l y s i n e}$ (New England Nuclear; specific activity $0.1 \mathrm{mCi} / \mathrm{ml}$ ) was added and the cultures were oxygenated $30 \mathrm{~s}$ before continuing incubation at $37^{\circ} \mathrm{C}$ for $48 \mathrm{~h}$ in a shaking water bath. The calvaria were washed in distilled $\mathrm{H}_{2} \mathrm{O}$ and homogenized in buffered saline $(0.9 \% \mathrm{NaCl}$ adjusted to $\mathrm{pH} 7.4$ with a solution of $1 \mathrm{M} \mathrm{Na} \mathrm{NO}_{3}$ ) and suspended in $10 \mathrm{ml}$ of the same buffer along with $2 \mathrm{mg}$ of sodium borohydride (Sigma Chemical Co.). Reduction proceeded at room temperature for $1 \mathrm{~h}$ with occasional stirring, and then a few drops of glacial acetic acid were added to stop the reduction by lowering the $\mathrm{pH}$ to 4.0 . The samples were dialyzed against 16 liters of distilled $\mathrm{H}_{2} \mathrm{O}$ at $4^{\circ} \mathrm{C}$ with one change over 2 days. The samples were lyophilized and 25 $\mathrm{mg}$ were hydrolyzed in $6 \mathrm{~N} \mathrm{HCl}$ for $24 \mathrm{~h}$ at $105^{\circ} \mathrm{C}$.

Separation and identification of radioactive collagen crosslinks required a modified amino acid analyzer and ion exchange chromatography with pyridine-formic acid buffers. Samples were dissolved in $1.0 \mathrm{ml}$ of $0.1 \mathrm{M}$ pyridine-formic acid buffer $\mathrm{pH}$ 2.9. Amino acids and radioactive collagen cross-links were eluted from a $0.9-\mathrm{cm} \times 54-\mathrm{cm}$ column filled with Beckman

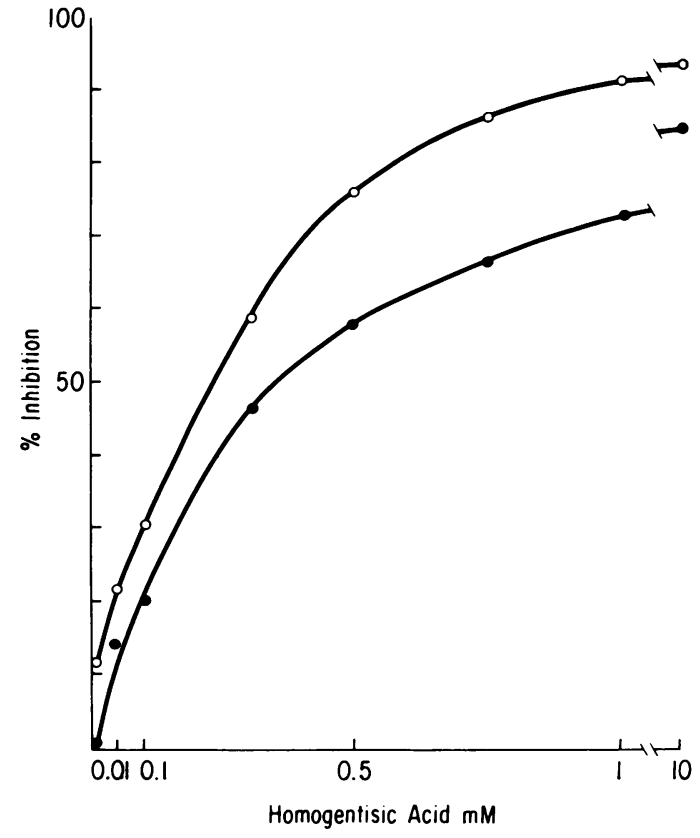

FIGURE 1 The inhibition of lysyl hydroxylase activity as a function of homogentisic acid concentration. Both assay systems contained $6.0 \times 10^{5} \mathrm{dpm}\left[4,5^{-3} \mathrm{H}\right]$ lysine-labeled collagen substrate, $1.0 \mathrm{mg}$ lysyl hydroxylase, $50 \mathrm{mM}$ Tris- $\mathrm{HCl}$ pH 7.8, $0.5 \mathrm{mM} \alpha$-ketoglutarate, $0.05 \mathrm{mM} \mathrm{FeSO}$, $0.5 \mathrm{mM}$ ascorbic acid. The whole assay system (O) contained, in addition, $0.1 \mathrm{mM}$ 1,4-dithiothreitol, $2.25 \mathrm{mg}$ bovine serum albumin, $0.15 \mathrm{mg}$ catalase; whereas the modified assay system (O) did not contain these three components. Both systems were incubated at $37^{\circ} \mathrm{C}$ for $90 \mathrm{~min}$. The whole assay system (O) had a control value of $3,675 \Delta \mathrm{dpm}$ and the modified assay system $(O)$ had a control value of $3,168 \Delta \mathrm{dpm}$.

resin (type M82 Beckman Instrument, BmgH, Munich, West Germany) kept a $57^{\circ} \mathrm{C}$ with a circulating water bath. The elution gradient was formed by running $1.0 \mathrm{M}$ pyridineformic acid pH 5.0 into a $350 \mathrm{ml}$ mixing chamber containing $0.1 \mathrm{M}$ pyridine-formic acid, $\mathrm{pH} 2.9$. The flow rate was $50 \mathrm{ml} / \mathrm{h}$ and $5 \mathrm{ml}$ fractions were collected. All pyridinecontaining buffers were made with ninhydrin-free pyridine prepared by redistilling the pyridine after refluxing with ninhydrin $2 \mathrm{~g} /$ liter. The column elutate was pumped through a Beckman $\beta$-mate II equipped with a flow-cell for constant monitoring of radioactive collagen cross-links as well as labeled lysine and hydroxylysine. The identity of radioactive cross-links was confirmed by chromatography of the isolated peaks on a Beckman amino acid analyzer and comparison with the elution of known cross-links. ${ }^{1}$

\section{RESULTS}

When homogentisic acid was added to the cell-free assay system, the formation of hydroxylysine was inhibited. The effective concentration range of homogentisic acid inhibition is between $0.01 \mathrm{mM}$ and $10 \mathrm{mM}$ with $50 \%$ inhibition being obtained at 0.16 mM (Fig. 1). When homogentisic acid was prepared

\footnotetext{
${ }^{1}$ Courtesy of A. J. Bailey, Langford, Bristol, England.
} 


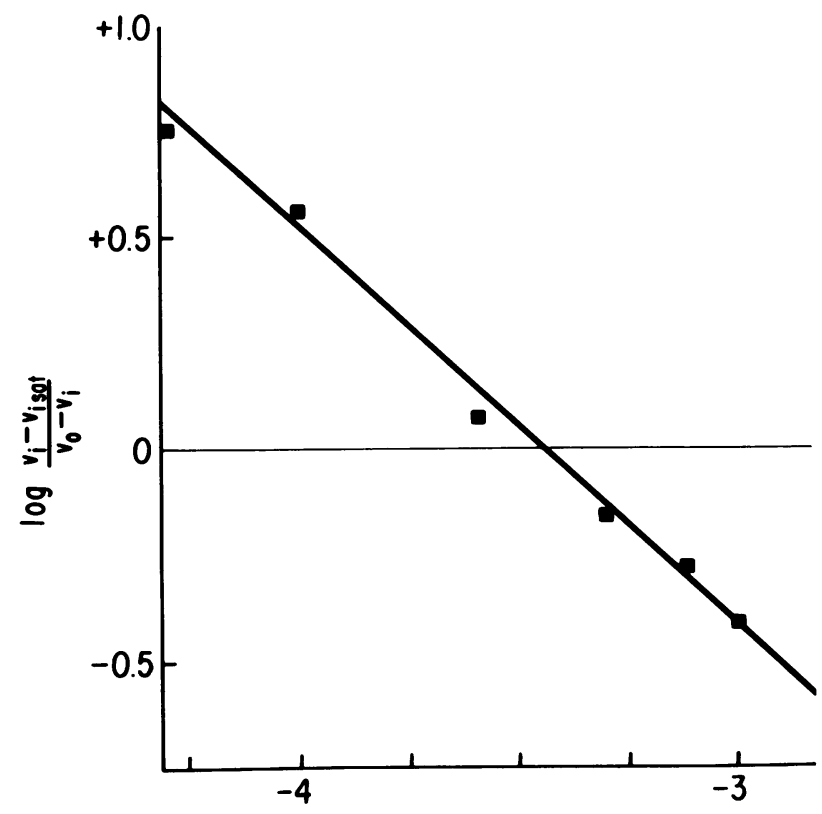

$\log I$

FIGURE 2 Determination of interaction coefficient of homogentisic acid and lysyl hydroxylase in the whole assay system. The coordinates of the plot in Fig. 1 for the whole assay system were used to obtain this line with negative slope $=0.91$. Inasmuch as this negative slope is $<1$, homogentisic acid demonstrates no cooperative interactions. The line was plotted with Vo $=3,675 \Delta \mathrm{dpm}$ and Vi sat $=0 \Delta \mathrm{dpm}$.

with alkali and aerated to produce its oxidation products and then added to the assay system, the same extent of inhibition of hydroxylysine formation was noted (data not shown).

When the coordinates of the plot for the whole assay system in Fig. 1 are applied to calculate an interaction coefficient (18), the negative slope of the plot (Fig. 2$)$ is $<1$. This slope $(m=0.91)$ means that homogentisic acid does not exhibit cooperative interactions in this system. The line is plotted with Vo $=3,675 \Delta \mathrm{dpm}$ and $\mathrm{Vi}$ sat $=0 \Delta \mathrm{dpm}$. The coordinates of the plot for the modified assay system in Fig. 1 also give an interaction coefficient $<1$ for homogentisic acid concentrations $<0.1 \mathrm{mM}$ which were used in the kinetic studies.

The extent of reversibility of homogentisic acid inhibition was demonstrated in the experiment where solutions of collagen substrate or lysyl hydroxylase preparation were preincubated with $15 \mathrm{mM}$ homogentisic acid and then dialyzed (Table I). Although, the activity of the enzyme mixed with $15 \mathrm{mM}$ homogentisic acid nearly doubled after extensive dialysis, $50 \%$ inhibition of control activity remained in the absence of cofactors. When cofactors were added to the mixture of enzyme and homogentisic acid, the rela- tive increase after dialysis was similar and $86 \%$ of control activity was obtained. When collagen substrate was preincubated with $15 \mathrm{mM}$ homogentisic acid in the presence or absence of cofactors, the increase in activity was noted from near $\mathbf{5 0 \%}$ inhibition before dialysis to 98 and $96 \%$ of control activity after dialysis.

The addition of excess cofactors ferrous ion and $\alpha$-ketoglutarate did not affect the inhibition of lysyl hydroxylase by homogentisic acid. With lysyl hydroxylase activity $61 \%$-inhibited by $0.5 \mathrm{mM}$ homogentisic acid, the addition of $0.75-2.5 \mathrm{mM} \alpha$-ketoglutarate did not increase activity and the addition of $0.075-0.25 \mathrm{mM}$ ferrous ion increased activity $5 \%$.

The addition of reducing agents such as ascorbic acid or 1,4-dithiothreitol prevented the inhibition of lysyl hydroxylase by homogentisic acid (Table II). Ascorbic acid and D-isoascorbic acid appeared equally effective in restoring lysyl hydroxylase activity at 33.3 and $66.6 \mu \mathrm{M}$ homogentisic acid, whereas dehydro-

\section{TABLE I}

Restoration of Lysyl Hydroxylase Activity with Dialysis, after Preincubation of Homogentisic Acid with Lysyl Hydroxylase or Unhydroxylated Collagen Substrate in the Presence or Absence of Cofactors

\begin{tabular}{|c|c|c|c|c|}
\hline & \multicolumn{2}{|c|}{ Before dialysis } & \multicolumn{2}{|c|}{ After dialysis } \\
\hline & $\Delta \mathrm{dpm}$ & $\begin{array}{c}\% \\
\text { control }\end{array}$ & $\Delta \mathrm{dpm}$ & $\begin{array}{c}\% \\
\text { control }\end{array}$ \\
\hline \multicolumn{5}{|c|}{ Lysyl hydroxylase and addition } \\
\hline None & 5,360 & & 5,570 & \\
\hline Homogentisic acid & 1,480 & 27.8 & 2,840 & 49.5 \\
\hline Cofactors & 5,940 & & 6,500 & \\
\hline $\begin{array}{l}\text { Cofactors and } \\
\text { homogentisic acid }\end{array}$ & 2,260 & 38.4 & 5,600 & 86.0 \\
\hline \multicolumn{5}{|c|}{$\left[4,5-{ }^{3} \mathrm{H}\right]$ lysine-labeled collagen substrate and addition } \\
\hline None & 1,760 & & 1,560 & \\
\hline Homogentisic acid & 895 & 51.0 & 1,540 & 97.5 \\
\hline Cofactors & 3,340 & & 2,700 & \\
\hline $\begin{array}{l}\text { Cofactors and } \\
\text { homogentisic acid }\end{array}$ & 1,520 & 45.6 & 2,620 & 97.0 \\
\hline
\end{tabular}

The preincubation was carried out at $4^{\circ} \mathrm{C}$ for $120 \mathrm{~min}$. Each solution with a volume of $1.5 \mathrm{ml}$ contained $15 \mathrm{mg}$ lysyl hydroxylase protein or $5.9 \times 10^{6} \mathrm{dpm}$ collagen substrate. Each solution with cofactors contained $0.05 \mathrm{mM} \mathrm{FeSO}_{4}$, $0.5 \mathrm{mM}$ ascorbic acid, $0.1 \mathrm{mM}$ 1,4-dithiothreitol, and $0.5 \mathrm{mM}$ $\alpha$-ketoglutarate. The preincubation mixtures contained $15 \mathrm{mM}$ homogentisic acid so that the assay concentration was $1 \mathrm{mM}$ before dialysis. After preincubation a $0.1-\mathrm{ml}$ aliquot of each solution was assayed for its effect on lysyl hydroxylase activity. The enzyme solutions were dialyzed against 4 liters of $0.05 \mathrm{M} \mathrm{NaCl}, 20 \mathrm{mM}$ Tris- $\mathrm{HCl} \mathrm{pH} 7.4$ at $4^{\circ} \mathrm{C}$ with five changes over $48 \mathrm{~h}$. The substrate solutions were dialzyed against 4 liters of $20 \mathrm{mM}$ Tris- $\mathrm{HCl} \mathrm{pH} 7.8$ at $4^{\circ} \mathrm{C}$ with five changes over $48 \mathrm{~h}$. 0.1-ml aliquots were taken for assays. 
ascorbic acid was not effective in preventing inhibition by homogentisic acid.

Kinetic analysis (Fig. 3) revealed a noncompetitive type of inhibition by homogentisic acid with respect to varying collagen substrate concentrations. The reciprocal plots were straight lines converging to intersection to the left of the $1 / \mathrm{V}$ axis and just below or near the $1 / \mathrm{S}$ axis. Both the slope and Y-intercept of these reciprocal lines varied with inhibitor concentration as shown by the replots (Fig. 4). The Ki calculated from these replots was $120-180 \mu \mathrm{M}$. Further kinetic analysis (Fig. 5) revealed a competitive type of inhibition by homogentisic acid with respect to varying concentrations of ascorbic acid. These reciprocal plots converged near the $1 / \mathrm{V}$ axis, and the replots of the slope and Y-intercepts against inhibitor concentration were linear.

The addition of homogentisic acid to tissue cultures of chick embryo calvaria inhibited lysine hydroxylation and subsequent formation of reducible intermolecular collagen cross-links (Fig. 6). The formation

\section{TABLE II}

Prevention of Homogentisic Acid Inhibition of Lysyl Hydroxylase Activity by the Addition of Ascorbic Acid, Ascorbic Acid Analogues, and 1,4-Dithiothreitol

\begin{tabular}{|c|c|c|c|}
\hline \multirow[b]{2}{*}{ Addition } & & \multicolumn{2}{|c|}{$\begin{array}{l}\Delta \text { dpm Lysyl hydrox- } \\
\text { ylase activity hom- } \\
\text { ogentisic acid, } \mu M\end{array}$} \\
\hline & & 33.3 & 66.6 \\
\hline None & 1,908 & 1,065 & 780 \\
\hline \multicolumn{4}{|l|}{ Ascorbic acid } \\
\hline $0.006 \mathrm{mM}$ & 2,621 & 1,420 & 977 \\
\hline $0.020 \mathrm{mM}$ & 3,215 & 1,910 & 1,393 \\
\hline $0.060 \mathrm{mM}$ & 3,730 & 2,860 & 2,187 \\
\hline \multicolumn{4}{|c|}{ D-Isoascorbic acid } \\
\hline $0.026 \mathrm{mM}$ & 1,887 & 1,202 & 600 \\
\hline $0.040 \mathrm{mM}$ & 2,446 & 2,190 & 1,410 \\
\hline $0.080 \mathrm{mM}$ & 2,847 & 2,860 & 1,990 \\
\hline \multicolumn{4}{|c|}{ Dehydroascorbic acid } \\
\hline $0.25 \mathrm{mM}$ & 1,551 & 1,460 & \\
\hline $0.50 \mathrm{mM}$ & 1,454 & 1,320 & 1,140 \\
\hline $0.75 \mathrm{mM}$ & 1,395 & 1,310 & 1,290 \\
\hline \multicolumn{4}{|c|}{ 1,4-Dithiothreitol } \\
\hline $0.016 \mathrm{mM}$ & 1,481 & 1,422 & \\
\hline $0.032 \mathrm{mM}$ & 1,989 & 1,947 & 1,915 \\
\hline $0.048 \mathrm{mM}$ & 2,280 & 2,246 & 2,412 \\
\hline
\end{tabular}

Each assay solution contained the following in $1.5 \mathrm{ml}$ : $6.6 \times 10^{5} \mathrm{dpm}\left[4,5-{ }^{3} \mathrm{H}\right]$ lysine-labeled collagen substrate, $1 \mathrm{mg}$ lysyl hydroxylase preparation, $50 \mathrm{mM}$ Tris- $\mathrm{HCl} \mathrm{pH} \mathrm{7.8,}$ $0.5 \mathrm{mM} \alpha$-ketoglutarate, $0.05 \mathrm{mM} \mathrm{FeSO}_{4}$ and $0.02 \mathrm{mM}$ ascorbic acid as well as 33.3 or $66.6 \mu \mathrm{M}$ homogentisic acid and the additions in the left column. The assays were incubated for $60 \mathrm{~min}$ at $37^{\circ} \mathrm{C}$.

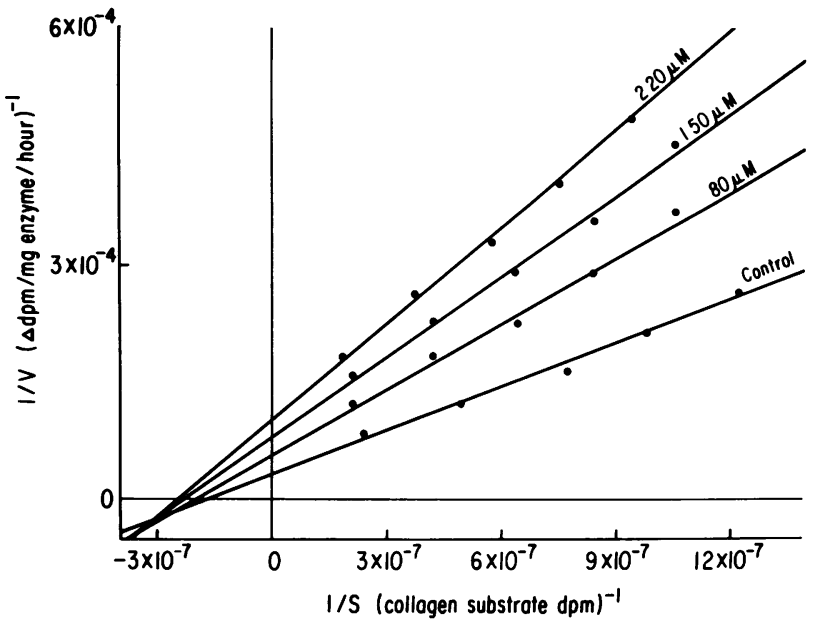

FIGURE 3 Double reciprocal plots of initial rate collagen lysyl hydroxylation and concentrations of $\left[4,5-{ }^{3} \mathrm{H}\right]$ lysinelabeled collagen substrate with 80,150 , and $220 \mu \mathrm{M}$ homogentisic acid. The modified assay system contained in 1.5 $\mathrm{ml}: 1.0 \mathrm{mg}$ lysyl hydroxylase preparation, $50 \mathrm{mM}$ Tris- $\mathrm{HCl}$ pH 7.8, 0.5 mM $\alpha$-ketoglutarate, $0.05 \mathrm{mM} \mathrm{FeSO}_{4}, 0.5 \mathrm{mM}$ ascorbic acid, and varying amounts of collagen substrate and homogentisic acid. The system was incubated at $37^{\circ} \mathrm{C}$ for $60 \mathrm{~min}$.

of hydroxylysine dropped from 65 to $29 \%$ of control values with $0.5-5 \mathrm{mM}$ homogentisic acid. The reduced intermolecular cross-links 5,5'-dihydroxylysinonorleucine (diOH-LNL) and 5-hydroxylysinonorleucine (OH-LNL) were dramatically decreased to $<33 \%$ of control values. The values for formation of hydroxylysine and intermolecular cross-links are calculated as fractions of total $\left[{ }^{14} \mathrm{C}\right]$ lysine incorporated into tissue so that the observed inhibition is not re-

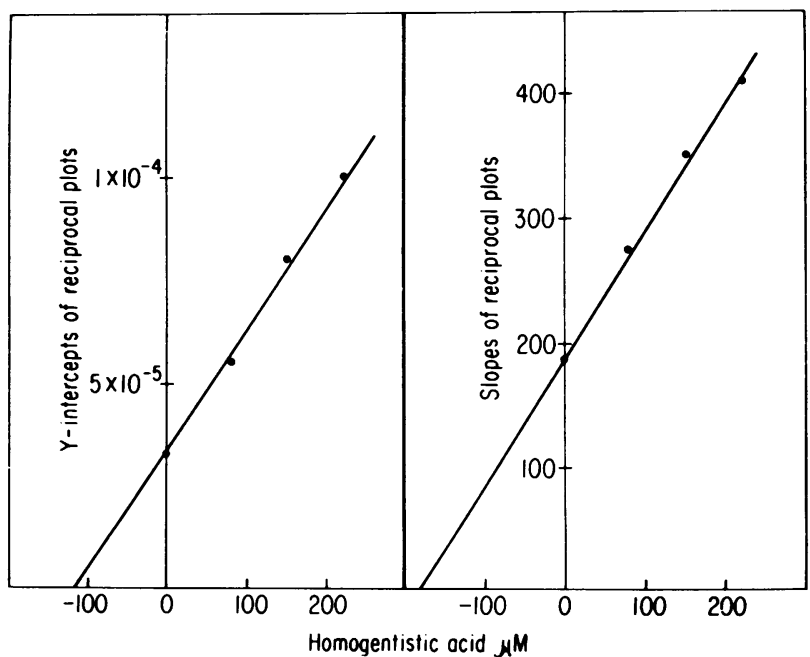

FIGURE 4 Replots of Y-intercepts and slopes from double reciprocal plots in Fig. 3 versus homogentisic acid concentration. 


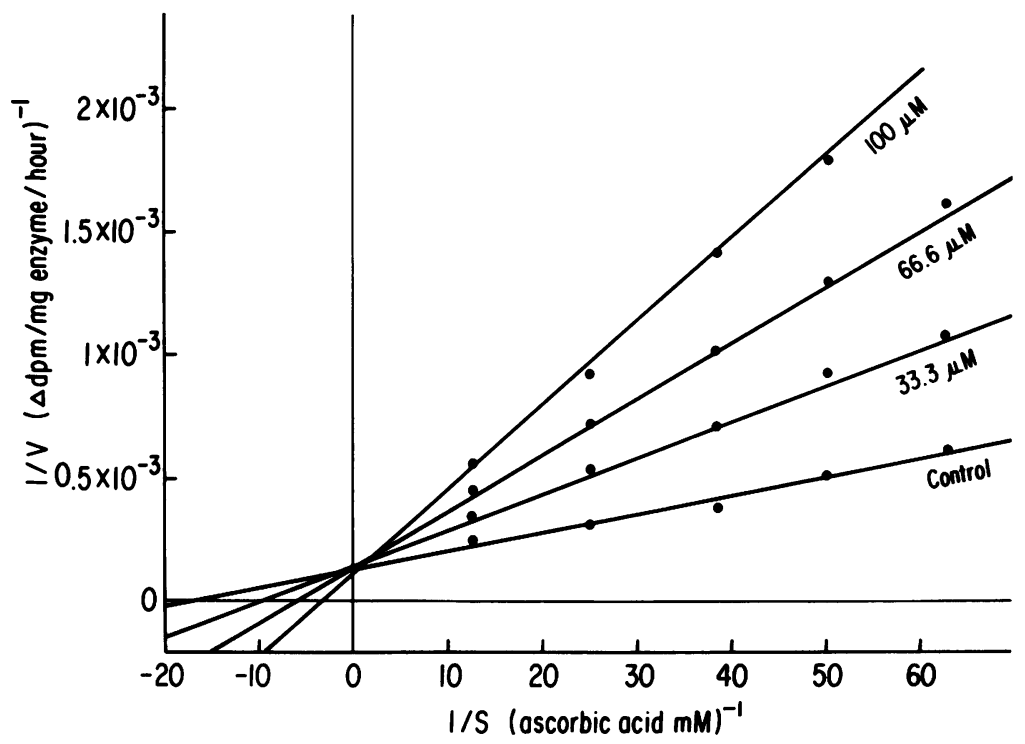

FIGURE 5 Double reciprocal plots of initial lysyl hydroxylation and concentrations of ascorbic acid with $33.3,66.6$, and $100 \mu \mathrm{M}$ homogentisic acid. The modified assay system is described in Methods. The assay system was incubated at $37^{\circ} \mathrm{C}$ for $60 \mathrm{~min}$.

lated to a toxic effect of homogentisic acid on the uptake of labeled lysine. The expressed percents are comparisons of values in treated samples to those of control samples. The same amount of tissue was analyzed to test the effect at each concentration.

Aliquots of the lyophilized samples which had not been hydrolyzed were digested with proteinase-free collagenase to measure newly synthesized radioactive collagen in the presence of other proteins in the tissue culture. The percent of newly synthesized collagen in Table III (control, 79\%; $5 \mathrm{mM}$ homogentisic acid, $74 \%$; $1 \mathrm{mM}$ homogentisic acid, $82 \%$; $0.5 \mathrm{mM}$ homogentisic acid, $84 \%$ ) did not diminish appreciably. The range of $\mathrm{dpm}$ in the collagenase digest was from 388 to 1,494 , and the range of $\mathrm{dpm}$ in the residue was from 265 to 653 . The amount of labeled lysine incorporated at each concentration was similar except at $5 \mathrm{mM}$, the toxic effect of which lowered lysine incorporation but did not preferentially inhibit collagen biosynthesis. These concentrations of homogentisic acid did not inhibit formation of hydroxylysine or cross-links by selectively impeding collagen biosynthesis.

\section{DISCUSSION}

Inhibition of chick embryo hydroxylysine formation by homogentisic acid was measured by several methods. With the in vitro tritium-release assay system, $0.16 \mathrm{mM}$ homogentisic acid inhibited 50\% of hydroxylysine formation (Fig. 1). Preliminary kinetic analysis revealed a noncompetitive type of inhibition with respect to collagen substrate (Fig. 3), and reversibility of this inhibition was demonstrated by the restoration of activity after dialysis had removed homogentisic acid from mixtures with substrate. Because dialysis of mixtures of lysyl hydroxylase and homogentisic acid partially reversed inhibition of hydroxylysine formation, homogentisate bound relatively tightly to lysyl hydroxylase except in the presence of ascorbic acid which was shown to be competitive with respect to homogentisate (Fig. 5). It appears that the inhibition of hydroxylysine formation does not result from irreversible binding of homogentisic acid or its oxidation products to reactive sites of either lysyl hydroxylase or the unhydroxylated collagen substrate.

Lysyl hydroxylase is a mixed-function oxygenase requiring $\mathrm{O}_{2}$, ferrous ion, ascorbic acid, and $\alpha$-ketoglutarate. The addition of excess ferrous ion or $\alpha$ ketoglutarate did not prevent inhibition of hydroxylysine formation by homogentisic acid. However, the addition of ascorbic acid or another reducing agent, such as 1,4-dithiothreitol, prevented the inhibition of hydroxylysine formation by homogentisic acid. Kinetic analysis revealed that homogentisic acid inhibition of hydroxylysine formation is competitive with respect to ascorbic acid concentration. The role of ascorbic acid or 1,4-dithiothreitol in the assay system for lysyl hydroxylase activity is not entirely understood. Without ascorbic acid, the assay system demonstrates minimal lysyl hydroxylase activity (11). Although 1,4dithiothreitol is not essential for hydroxylysine formation, 1,4-dithiothreitol in the assay system increases 
hydroxylysine formation to an optimal level. Inasmuch as sulfhydryl-binding compounds such as $p$ mercuribenzoate inhibit lysyl hydroxylase activity, ascorbic acid or a reducing agent may function by protecting sulfhydryl groups of the enzyme (9).

Although the nature of the inhibition of lysyl hydroxylase activity by homogentisic acid is unknown, reducing agents interact with homogentisic acid and lysyl hydroxylase to protect enzyme activity. Reducing agents prevent the oxidation of homogentisic acid to its respective $p$-quinone, benzoquinoneacetic acid (19). Both homogentisic acid and its oxidation product formed by bubbling oxygen through an alkaline solution of homogentisic acid were found to be equally effective in inhibiting hydroxylysine formation. Benzoquinoneacetic acid may be the active inhibitor of lysyl hydroxylase activity, since $p$-quinones are known to react spontaneously with sulfhydryl groups to form 1,4-addition products (20-23). Reducing

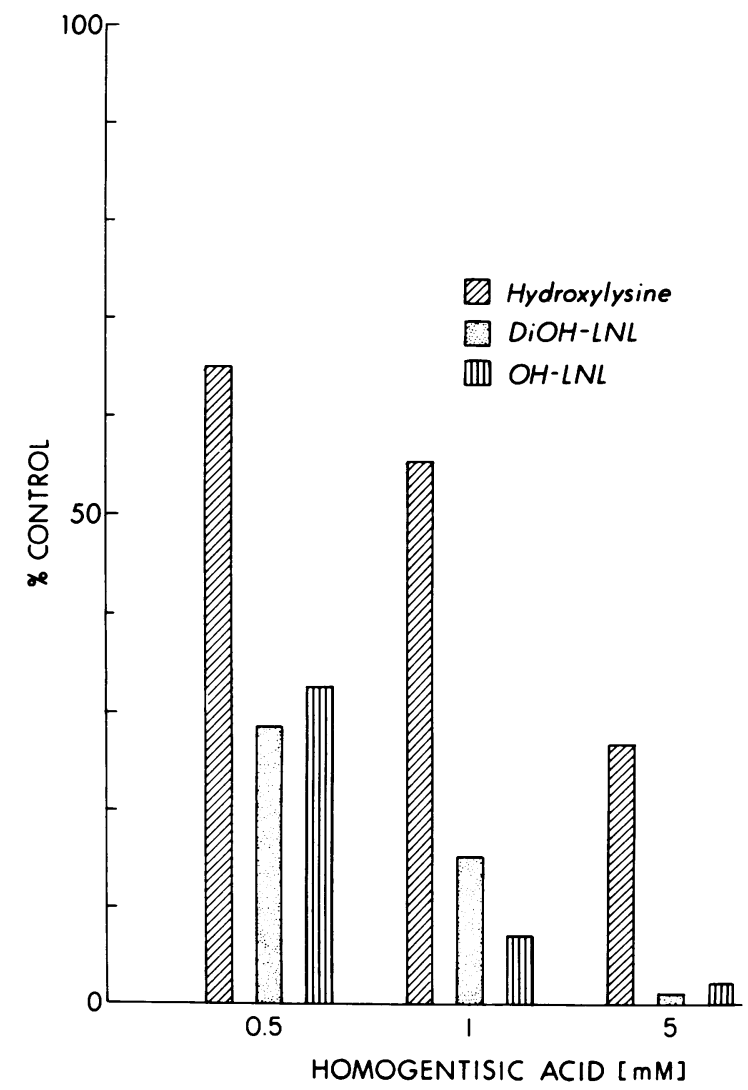

FIGURE 6 Inhibition of hydroxylysine and hydroxylysinederived cross-link formation in organ culture systems of chick embryo calvaria grown with homogentisic acid, as compared to the same organ culture system grown without homogentisic acid. DiOH-LNL, 5,5'-dihydroxylysinonorleucine; OH-LNL, 5-hydroxylysinonorleucine. The control values were as follows: $18,526 \mathrm{cpm}$ hydroxylysine $/ 10^{5} \mathrm{cpm}$ lysine, 5,282 cpm DiOH-LNL, 1,851 cpm OH-LNL.
TABLE III

Collagenase Digestion of Lyophilized Tissue from Chick Embryo Calvaria Organ Cultures Grown in the Presence of Homogentisic Acid

\begin{tabular}{cccc}
\hline $\begin{array}{c}\text { Homogentisic } \\
\text { acid }\end{array}$ & $\begin{array}{c}\text { Collagenase- } \\
\text { sensitive }\end{array}$ & Residue & $\begin{array}{c}\text { Collagen } \\
\text { biosynthesis }\end{array}$ \\
\hline$m M$ & $\Delta d \nu m$ & $d p m$ & $\%$ \\
None & 1,318 & 653 & 79 \\
5.0 & 388 & 265 & 74 \\
1.0 & 1,494 & 620 & 82 \\
0.5 & 1,349 & 478 & 84 \\
\hline
\end{tabular}

Lyophilized tissue at each concentration was prepared according to the substrate preparation described by Diegelmann et al. (12). The assays contained in $0.5 \mathrm{ml}: 0.1 \mathrm{mg}$ substrate, $50 \mathrm{U}$ form III collagenase (Advance Biofactures Corp.), $100 \mu \mathrm{M}$ HEPES buffer ( $N$-2-hydroxyethylpiperazine $N^{\prime}$-2-ethanesulfonic acid) $\mathrm{pH} 7.2$ (Calbiochem), $0.25 \mu \mathrm{M}$ $\mathrm{CaCl}_{2}$. The assay was incubated for $90 \mathrm{~min}$ at $37^{\circ} \mathrm{C}$ and the percent collagen biosynthesis was calculated from the formula given in Methods.

agents may protect hydroxylysine formation by preventing either oxidation of homogentisic acid to benzoquinoneacetic acid or interaction of a homogentisic acid derivative with lysyl hydroxylase.

Further evidence of the inhibition of hydroxylysine formation by homogentisic acid was demonstrated by the organ culture system of chick embryo calvaria. Comparable levels of inhibition of hydroxylysine formation for the same homogentisic acid concentrations were noted in this system as those in the tritiumrelease assay system. This organ culture experiment suggests that homogentisic acid may pass through the cell membrane to interfere with the intracellular hydroxylation of lysyl residues in collagen. A diminished amount of hydroxylysine in newly synthesized collagen would be expected to be reflected in a diminution of hydroxylysine-derived collagen cross-links. Lowered amounts of intermolecular cross-links would be expected to result in decreased structural integrity of collagen fibrils. Unfortunately, fibroblasts from patients with alkaptonuria do not manifest the enzymatic defect and are unsuitable for studying the collagen biosynthetic defect (24).

Although the hydroxylysine or cross-link content of human ochronotic collagen as well as lysyl hydroxylase activity of these tissues is presently unknown, the inhibition of hydroxylysine formation by homogentisic acid may explain the predilection of alkaptonuric complications for hydroxylysine-rich tissue. Different tissues contain characteristic types of collagen with unique hydroxylysine contents. Dermis contains mostly type I collagen which has 5.8 residues of hydroxylysine per 1,000 amino acids (25). Articular cartilage, on the other hand, contains predominantly 
type II collagen which has 14 hydroxylysine residues per 1,000 amino acids (26). Moreover, cartilage collagen contains an intermolecular cross-link $\Delta^{6}$-dehydro-5,5' dihydroxylysinonorleucine derived from two hydroxylysyl residues (27). This cross-link is particularly stable because it undergoes Amadori rearrangement which permits the aldimine cross-link to be converted to a keto-amino cross-link (28). Because collagen in articular cartilage is hydroxylysine-rich and depends upon cross-links involving two hydroxylysine residues for its structural integrity, articular cartilage might be expected to be more affected by the inhibition of hydroxylysine formation by homogentisic acid.

Type II collagen also differs from type I by having a greater extent of hydroxylysine glycosylation. Studies with chick sternal cartilage have shown that of the 23 residues of hydroxylysine per 1,000 amino acids, approximately 5 are linked to glycosylgalactose and about 4 are linked to galactose (29). Although the function of these glycosides is unknown, evidence has been presented that glycosylated hydroxylysine is involved in cross-link formation $(6,7)$. Cross-links derived from both one and two hydroxylysyl residues contain glycosylated derivatives that are present in varying proportions for different tissues (6). Inasmuch as formation of hydroxylysine is critical for the attachment of carbohydrate to collagen, any reduction of hydroxylysine content by homogentisic acid would also impair formation of cross-links with glycosylated derivatives.

Another alkaptonuric complication that may involve hydroxylysine-rich collagen is cardiovascular disease. Purified pepsin-solubilized heart valve collagen $\alpha$ chains are similar to those of type I collagen but contain twice as much hydroxylysine and 5-10 times more carbohydrate than comparable type I collagen chains (30). The association of cardiovascular disease in alkaptonuric patients may be explained by an increased susceptibility of hydroxylysine-rich collagen to the inhibition by homogentisic acid.

The clinical course of ochronotic complications suggests that the connective tissue deterioration is a gradual and progressive process. Because alkaptonuric patients lack homogentisic acid oxidase from birth, their tissues are exposed to excess homogentisic acid for a lifetime. Although no data is available about the long-term concentration of homogentisic acid in synovial fluid of alkaptonuric patients, blood levels in excess of $0.1 \mathrm{mM}$ homogentisic acid have been reported (31). If the articular cartilage is exposed to $0.1 \mathrm{mM}$ homogentisic acid over several decades, a low (30\%) inhibition of lysyl hydroxylase activity may compromise the structural integrity of collagen. The continual dynamic process of degradation and deposition of collagen in the presence of homogentisic acid might produce defective connective tissue without adequate hydroxylysine-derived cross-links. Inasmuch as ascorbic acid protects lysyl hydroxylase activity from inhibition by homogentisic acid, long-term ascorbic acid therapy in alkaptonuric patients would seem reasonable to modify the predictable connective tissue disability.

\section{ACKNOWLEDGMENTS}

This work was supported by National Institutes of Health grant no. 5 R01-AM-17128 and by a grant from HoffmannLaRoche.

\section{REFERENCES}

1. Gallop, P. M., O. O. Blumenfeld, and S. Seifter. 1972. Structure and metabolism of connective tissue proteins. Annu. Rev. Biochem. 41: 617-672.

2. Tanzer, M. L. 1973. Cross-linking of collagen: endogenous aldehydes in collagen react in several ways to form a variety of unique covalent cross-links. Science (Wash. D. C.). 180: 561-566.

3. Bailey, A. J., S. R. Robins, and G. Balian. 1974. Biological significance of the intermolecular crosslinks of collagen. Nature (Lond.). 251: 105-109.

4. Butler, W. T., and L. W. Cunningham. 1966. Evidence for linkage of a disaccharide to hydroxylysine in tropocollagen. J. Biol. Chem. 241: 3882-3888.

5. Spiro, R. G. 1969. Characterization and quantitative determination of the hydroxylysine-linked carbohydrate units of several collagens. J. Biol. Chem. 244: 602-612.

6. Robins, S. P., and A. J. Bailey. 1974. Isolation and characterization of glycosyl derivatives of the reducible cross-links in collagens. FEBS (Fed. Eur. Biochem. Soc.) Lett. 38: 334-336.

7. Eyre, D. R., and M. J. Glimcher. 1973. Analysis of a crosslinked peptide from calf bone collagen: evidence that hydroxylysyl glycoside participates in the crosslink. Biochem. Biophys. Res. Commun. 52: 663-671.

8. Murray, J. C., K. A. Lindberg, and S. R. Pinnell. 1976. Inhibition of lysyl hydroxylase by homogentisic acid: a proposed connective tissue defect in alcaptonuria. Clin. Res. 24: 15A. (Abstr.)

9. Kivirikko, K. I., and D. J. Prockop. 1972. Partial purification and characterization of protocollagen lysine hydroxylase from chick embryos. Biochim. Biophys. Acta. 258: 366-379.

10. Layne, E. 1957. Spectrophotometric and turbidimetric methods for measuring proteins. Methods Enzymol. 3: 447-454.

11. Miller, R. L. 1972. Rapid assay for lysyl-protocollagen hydroxylase activity. Anal. Biochem. 45: 202-210.

12. Diegelmann, R. F., L. C. Rothkopf, and I. K. Cohen. 1975. Measurement of collagen biosynthesis during wound healing. J. Surg. Res. 19: 239-243.

13. Kang, A. H., K. A. Piez, and J. Gross. 1969. Characterization of the $\alpha$ chains of chick skin collagen and the nature of the $\mathrm{NH}_{2}$-terminal cross-link region. Biochemistry. 8: 3648-3655.

14. Sober, H. A., editor. 1970. Handbook of Biochemistry: Selected Data for Molecular Biology. Chemical Rubber Co., Cleveland, Ohio. C-282-C-287.

15. Diegelmann, F. R., and B. Peterkofsky. 1972. Collagen biosynthesis during connective tissue development in chick embryo. Dev. Biol. 28: 443-453.

16. Segel, I. H. 1975. Enzyme Kinetics. John Wiley \& Sons, Inc., New York. 934-935. 
17. Bailey, A. J., C. M. Peach, and L. J. Fowler. 1970. Chemistry of collagen cross-links: isolation and characterization of two intermediate intermolecular crosslinks in collagen. Biochem. J. 117: 819-831.

18. Jensen, R. A., and E. W. Nester. 1966. Regulatory enzymes of aromatic amino acid biosynthesis in Bacillus subtilis. II. The enzymology of feedback inhibition of 3-deoxy-D-arabino-heptolosonate 7-phosphate synthetase. J. Biol. Chem. 241: 3373-3380.

19. Zannoni, V. G., S. E. Malawista, B. N. La Du. 1962. Studies on ochronosis. II. Studies on benzoquinoneacetic acid, a probable intermediate in the connective tissue pigmentation of alcaptonuria. Arthritis Rheum. 5: 547556.

20. Snell, J. M., A. Weissberger. 1939. The reaction of thiol compounds with quinones. J. Am. Chem. Soc. 61: 450-453.

21. Shubert, M. 1947. The interaction of thiols and quinones. J. Am. Chem. Soc. 69: 712-713.

22. Fieser, L. F., R. B. Turner. 1947. The addition of sulfhydryl derivatives to 2-methyl-1,4-naphthoquinone. J. Am. Chem. Soc. 69: 2335-2338.

23. Mason, H. S. 1955. Comparative biochemistry of the phenolase complex. Adv. Enzymol. Relat. Areas Mol. Biol. 16: 120-122.

24. McKusick, V. A. 1972. Alcaptonuria: Heritable Disorders of Connective Tissue. The C. V. Mosby Company, St. Louis. 4th edition. 455-474.
25. Bornstein, P., and K. A. Keiz. 1964. A biochemical study of human skin collagen and the relation between intraand intermolecular cross-linking. J. Clin. Invest. 43: 1813-1823.

26. Miller, E. J., and L. G. Lunde. 1973. Isolation and characterization of the cyanogen bromide peptides from the $\alpha_{1}$ (II) chain of bovine and human cartilage collagen. Biochemistry. 12: 3153-3159.

27. Miller, E. J. 1971. Collagen cross-linking: identification of two cyanogen bromide peptides containing sites of intermolecular cross-link formation in cartilage collagen. Biochem. Biophys. Res. Commun. 45: 444-451.

28. Miller, E. J., and P. B. Robertson. 1973. The stability of collagen cross-links when derived from hydroxylysyl residues. Biochem. Biophys. Res. Commun. 54: 432439.

29. Miller, E. J. 1971. Isolation and characterization of a collagen from chick cartilage containing three identical $\alpha$ chains. Biochemistry. 10: 1652-1659.

30. Collins, D., B. McLees, and S. R. Pinnell. 1975. Characterization of heart valve collagen. Clin. Res. 23: 177A. (Abstr.)

31. LaDu, B. N. 1972. Alcaptonuria. In The Metabolic Basis of Inherited Disease. J. B. Stanbury, J. B. Wyngaarden, D. S. Fredrickson, editors. McGraw-Hill Book Co., New York. 3rd edition. 308-325. 